\title{
Completely $N^{i}$-Selective Palladium-Catalyzed Arylation of Unsymmetric Imidazoles: Application to the Synthesis of Nilotinib
}

\author{
Satoshi Ueda, Mingjuan Su, and Stephen L. Buchwald ${ }^{*}$ \\ Department of Chemistry, Massachusetts Institute of Technology, Cambridge, MA 02139
}

\begin{abstract}
The completely $N^{1}$-selective Pd-catalyzed arylation of unsymmetric imidazoles with aryl halides and triflates is described. This study showed that imidazoles have a strong inhibitory effect on the in situ formation of catalytically-active $\operatorname{Pd}(0)$-ligand complex. The efficacy of the $N$-arylation reaction was improved drastically by the use of pre-activated solution of $\operatorname{Pd}_{2}(\mathrm{dba})_{3}$ and $\mathbf{L 1}$. From these findings it is clear that while imidazoles can prevent binding of $\mathbf{L 1}$ to the Pd, once the ligand is bound to the metal, these heterocycles do not displace it. The utility of the present catalytic system was demonstrated by the regioselective synthesis of clinically important tyrosine kinase inhibitor nilotinib.
\end{abstract}

\section{Keywords}

Palladium; Arylation; Imidazole; Benzimidazole; Aryl Halide; Nilotinib

\section{Introduction}

4-Substituted $N^{1}$-arylimidazoles represent key structural motifs in medicinally important compounds including tyrosine kinase inhibitors, ${ }^{1} \gamma$-secretase modulators, ${ }^{2}$ serotonin receptor antagonists $^{3}$ and glycine transporter type-1 inhibitors (Figure 1). ${ }^{4}$

Traditionally, $N$-arylimidazoles have been prepared via an $\mathrm{S}_{\mathrm{N}} \mathrm{Ar}$ process or classical Ullmann-type coupling with stoichiometric copper. In the former case, aryl donors are limited to aryl halides with strong electron-withdrawing groups or activated heteroaryl halides. ${ }^{5}$ The classical Ullmann coupling has a broader substrate scope; however, the reaction requires long reaction time under high temperature $\left(150-200^{\circ} \mathrm{C}\right)$, which limits its functional group tolerance. Over the past decade, there has been remarkable progress in the development of Cu-catalyzed $\mathrm{N}$-arylation methods of imidazoles with aryl halides ${ }^{6}$ or aryl boronic acids. ${ }^{7}$ Due to its broad scope under mild conditions, along with low-cost and lowtoxicity of copper salts, the $\mathrm{Cu}$-catalyzed $\mathrm{N}$-arylation method quickly found many applications in medicinal chemistry and material science fields. ${ }^{8}$ However, due to the tautomeric nature of unsymmetric $1 \mathrm{H}$-imidazoles, the Cu-catalyzed arylation and $\mathrm{S}_{\mathrm{N}} \mathrm{Ar}$ reactions of the 4-substituted imidazoles oftentimes give poor to moderate regioselectivities. ${ }^{9}$ In addition, the similar physical properties of the $N^{1}$-aryl and $N^{3}$-aryl regioisomers oftentimes make separation of products difficult. Therefore, development of

sbuchwal@mit.edu.

Supporting Information Available: Complete ref 1a and 20d, experimental procedures, product characterization and copies of ${ }^{1} \mathrm{H}$ and ${ }^{13} \mathrm{C}$ NMR spectra. This material is available free of charge via the Internet at http://pubs.acs.org. 
general catalytic methods that selectively produce the $N^{1}$-arylated product from tautomeric 4-substituted imidazoles, while challenging, would be particularly valuable. ${ }^{10}$

During the past few decades, extensive effort from different groups has led to the discovery of a wide variety of Pd-catalyzed methods for the formation of $\mathrm{C}-\mathrm{N}$ bonds at aromatic systems. ${ }^{11}$ Although the Pd-catalyzed $N$-arylation of a variety of nitrogen nucleophiles including amines/anilines, ${ }^{12}$ imines, ${ }^{13}$ amides,${ }^{14}$ indoles, ${ }^{15}$ hydrazine,,${ }^{16}$ hydrazones,${ }^{17}$ ammonia, ${ }^{18}$ and nitrite ${ }^{19}$ has been well documented, the corresponding $N$-arylation of imidazoles is still not satisfactory; only a few reports of the Pd-catalyzed $\mathrm{N}$-arylation of imidazoles have appeared, and these have mostly been applied to a small number of activated aryl bromides and chlorides. ${ }^{20}$ In 2006, our group reported the Pd-catalyzed $\mathrm{N}$ arylation of imidazole with unactivated aryl bromide (4-bromotoluene) using biaryl phosphine L1 ${ }^{21}$ However, the reaction required relatively high catalyst loadings (5 mol \% $\mathrm{Pd}$ and $10 \mathrm{~mol} \% \mathbf{L 1}$ ) and the reaction gave $N$-arylated product in only a moderate yield even after $24 \mathrm{~h}$. In addition, reactions of 4-substituted imidazoles, functionalized aryl halides and heteroaryl halides were not disclosed. Herein, we report a full account of our investigations of completely $N^{1}$-selective arylation of imidazoles and disclose a significantly improved Pd-catalyzed protocol. Usefulness of the completely $N^{1}$-selective arylation of unsymmetric 4-substituted imidazoles was demonstrated by the regioselective syntheses of medicinally important compounds GSK2137305 and nilotinib.

\section{Results and Discussion}

\section{Design and development of the completely $\boldsymbol{N}^{\mathbf{1}}$-selective arylation of 4-methylimidazole}

Scheme 1 shows some of the presumed intermediates for the Pd-catalyzed $\mathrm{N}$-arylation of 4substituted imidazoles.

We reasoned that selective formation of the $N^{1}$-arylated product might be achievable due to unfavorable steric interactions in $\mathbf{B}^{\prime}$ relative to $\mathbf{B}$. The idea was supported by density functional theory (DFT) calculations with $\mathbf{L 1}$; complex $\mathbf{B}$ was favored over complex $\mathbf{B}^{\prime}$ and the transition states for the reductive elimination (B-TS and $\mathbf{B}^{\prime}$-TS) were also significantly different $\left(\Delta \Delta G^{\ddagger}=5.1 \mathrm{kcal} / \mathrm{mol}\right)$ in favor of the transition state to the $N^{1}$-arylated product (Figure 2).

To test the above hypothesis, we investigated the $N$-arylation of 4-methylimidazole with bromobenzene with a variety of phosphine ligands (Table 1 ). An examination of reaction conditions revealed that the use of $\mathrm{Pd}_{2}(\mathrm{dba})_{3}(0.75 \mathrm{~mol} \%)$, $\mathbf{L 1}(1.8 \mathrm{~mol} \%)$ and $\mathrm{K}_{3} \mathrm{PO}_{4}$ selectively produced $N^{1}$-arylated product, albeit only in $6 \%$ yield (entry 1 ). The examination of other structurally related biaryl phosphine ligands (L2-L5) and bases $\left(\mathrm{Cs}_{2} \mathrm{CO}_{3}, \mathrm{~K}_{2} \mathrm{CO}_{3}\right.$, $\mathrm{NaO} t \mathrm{Bu}$ ) provided no improvement in reaction efficacy (entries 2-8). Similarly, we obtained no $N$-arylation product with $\mathbf{L 6}, \mathbf{L 7}$ or $\mathbf{L 8}$ (entries 9-11), which were previously employed for the $N$-arylation of unsubstituted imidazole with activated aryl bromides ${ }^{20 \mathrm{a}}$ and chlorides ${ }^{20 \mathrm{~b}}$ in the presence of $\mathrm{Pd}(\mathrm{OAc})_{2}$ using the reported protocol published for each of these ligands. Further experimentations using $\mathbf{L} 1$ revealed that an improved yield (66\%) could be obtained by employing higher catalyst loading ( $5 \mathrm{~mol} \% \mathrm{Pd}$ and $10 \mathrm{~mol} \%$ L1), however, the reaction was sluggish and full conversion of bromobenzene was not achieved even after $20 \mathrm{~h}$ (entry 12). Since imidazoles are known to be ligands in $\mathrm{Pd}(0)$-catalyzed reactions, ${ }^{22}$ we suspected that the ineffectiveness of the reaction might be due to prevention of the in situ formation of the catalytically-active phosphine-ligated $\operatorname{Pd}(0)$ complex by excess 4-methylimidazole. Thus, we heated a premixed solution of $\mathrm{Pd}_{2}(\mathrm{dba})_{3}$ and $\mathbf{L} \mathbf{1}$ in the solvent for $3 \mathrm{~min}$ at $120^{\circ} \mathrm{C}$ prior to the injection to other reagents. With this protocol, the preactivated catalyst solution $\left(\mathrm{Pd}_{2}(\mathrm{dba})_{3} / \mathbf{L} \mathbf{1}\right)$ showed high activity and the $N^{1}$-arylated product was obtained in $97 \%$ GC yield (95\% isolated yield) in $5 \mathrm{~h}$ with $1.5 \mathrm{~mol} \% \mathrm{Pd}$ and 
$1.8 \mathrm{~mol} \% \mathbf{L 1}$ (entry 13). ${ }^{23,24}$ To further understand the source of inhibition of the reaction (entry 1 vs 13 ), imidazoles and each of the reaction components $\left(\mathrm{K}_{3} \mathrm{PO}_{4}\right.$ and $\left.\mathrm{PhBr}\right)$ were, in separate experiments, added to the premixed solution of $\mathrm{Pd}_{2}(\mathrm{dba})_{3}$ and $\mathbf{L 1}$ (Scheme 2). When the catalyst premixing was peformed in the presence of 4-methylimidazole, the reaction was significantly less efficient and the product was obtained only in $4 \%$ yield (Scheme 2, entry 1). Similarly, 1-methylimidazole showed inhibitory effect on the reaction (entry 2). On the other hand, addition of 1-methylpyrrole, bromobenzene or $\mathrm{K}_{3} \mathrm{PO}_{4}$ to the premixing solution did not significantly affect the reaction outcome and the product was obtained in high yields (entries 3-5). To observe the effect of 4-methylimidazole on the in situ formation of active catalyst, ${ }^{31} \mathrm{P}$ NMR signal of $\mathbf{L 1}$ was monitored at the catalyst premixing step (Figure 3). New phosphorus signals at $88 \mathrm{ppm}$ and $91 \mathrm{ppm}$ appeared after heating $\mathbf{L} 1$ and $\operatorname{Pd}_{2}(\mathrm{dba})_{3}$ in toluene at $120^{\circ} \mathrm{C}$, for $3 \mathrm{~min},{ }^{25}$ while only free $\mathbf{L} \mathbf{1}$ was observed when $\mathbf{L} \mathbf{1}$ and $\operatorname{Pd}_{2}(\mathrm{dba})_{3}$ were heated in the presence of excess 4-methylimidazole, suggesting that 4-methylimidazole prevents in situ ligand binding to $\operatorname{Pd}(0)$. Overall, our investigation led to the conclusions that (1) L1 is the highly effective ligand for the Pdcatalyzed $\mathrm{N}$-arylation of 4-methylimidazole and (2) imidazoles have an inhibitory effect on the in situ formation of catalytically-active $\mathrm{Pd}(0)$-ligand complex, and therefore, $\mathbf{L} \mathbf{1}$ and $\mathrm{Pd}_{2}(\mathrm{dba})_{3}$ should be pre-heated together in the solvent before they were exposed to the imidazoles. Of great significance is that while 4-methylimidazole prevents the binding of $\mathbf{L} \mathbf{1}$ to the Pd center, once the ligand is bound it is not displaced by the imidazole.

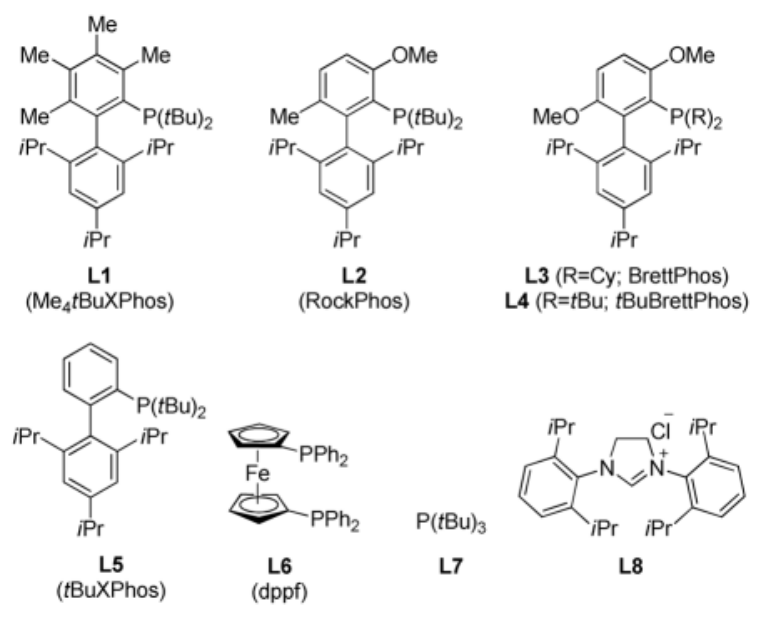

\section{Substrate scope of $\mathbf{N}$-arylation of 4 -substituted imidazole}

With an optimized protocol in hand, we next investigated the scope of the $\mathrm{N}$-arylation of unsymmetric imidazoles and benzimidazoles (Table 2). The Pd-catalyzed $N^{1}$-selective arylation was highly general and a variety of functionalized aryl bromides and chlorides could be employed for the arylation of 4-methylimidazole (entries 1-9), 4-phenylimidazole (entries 12-13), $\mathrm{N}$-acetylhistamine (entry 14) and 4-cyanomethylimidazole (entries 15-16) using 0.5-2.5 mol \% Pd. In addition, aryl triflates were suitable substrates (entries 10-11). To the best of our knowledge, this is the first example of $N$-arylation of imidazole derivatives with aryl triflates. No $N^{3}$-arylated regioisomers were detected in all cases examined. The $N$-arylation of 4-substituted imidazoles with 3 -halopyridines (entries 4 and 12), 2-bromopyridines (entries 8 and 15) and chloropyrazine (entry 16) demonstrates the utility of the method with heteroaryl substrates. Lastly, the $\mathrm{N}$-arylation of 4-substituted benzimidazoles exclusively occurred at less sterically hindered $N^{1}$ position to give $N^{1}$ arylated benzimidazoles in good yields (entries 17-18). 


\section{Synthesis of GSK2137305}

GSK2137305 is a potent glycine transporter inhibitor developed by GlaxoSmithKline for the treatment of neurological disorders. Previously, the $N^{1}$-aryl-4-methylimidazole 2 was synthesized by the $\mathrm{Cu}$-catalyzed $\mathrm{N}$-arylation of 4-methylimidazole with aryl bromide $\mathbf{1 a}$. Although the $\mathrm{Cu}$-catalyzed $\mathrm{N}$-arylation proceeded under ligand-free condition, approximately 4:1 mixture of $N^{1}$ - and $N^{3}$-arylated product was formed and yield of only $54 \%$ was obtained. ${ }^{4}$ Using $0.1 \mathrm{~mol} \% \mathrm{Pd}_{2}(\mathrm{dba})_{3}$ and $0.2 \mathrm{~mol} \% \mathrm{L1}, \mathrm{N}$-arylation of 4methylimidazole with aryl bromide 1a gave $\mathbf{2}$ in $93 \%$ yield as a single regioisomer (Scheme 3). Alternatively, aryl chloride substrate $\mathbf{1 b}$, which was prepared from less expensive 4chlorobenzaldehyde, ${ }^{26}$ could be employed for the $N$-arylation reaction with $0.15 \mathrm{~mol} \%$ $\mathrm{Pd}_{2}(\mathrm{dba})_{3}$ and $0.3 \mathrm{~mol} \% \mathbf{L 1}$. Subsequent $N$-alkylation of 2 afforded GSK2137305 (3) in $82 \%$ yield.

\section{Synthesis of nilotinib (Tasigna ${ }^{\circledR}$ )}

The usefulness of the Pd-catalyzed $N^{1}$-selective arylation of 4-substituted imidazoles was further demonstrated by the synthesis of the clinically important anti-cancer drug nilotinib (Scheme 4). Nilotinib (Tasigna ${ }^{\circledR}$ ) is a second-generation $B C R-A B L$ tyrosine kinase inhibitor that shows greater efficacy compared to imatinib (Gleevec $($ ) $)$ in the treatment of chronic myelogenous leukemia (CML), including Gleevec-resistant patients. ${ }^{1}$ In the previous syntheses of nilotinib, 4-methylimidazole was introduced by moderately regioselective reactions such as the $\mathrm{S}_{\mathrm{N}} \mathrm{Ar}$ reaction with an aryl fluoride ${ }^{27}$ or Cu-catalyzed $\mathrm{N}$-arylation with an aryl bromide. ${ }^{28,29}$ Using $0.25 \mathrm{~mol} \% \mathrm{Pd}_{2}(\mathrm{dba})_{3}$ and $0.5 \mathrm{~mol} \% \mathbf{L 1}$, key intermediate 5 was prepared from aryl bromide 4 in $90 \%$ yield as a single regioisomer. Use of excess (2.4 eq.) 4-methylimidazole, toluene- $t \mathrm{BuOH}$ mixed solvent and lower concentration $(0.5 \mathrm{M}$ $\mathrm{ArBr}$ ) were found to be important to supress undesirable $N$-arylation of aniline nitrogen of 4 and 5 . Ester 8 could be prepared from aminopyrimidine $\mathbf{6}$ and aryl bromide 7 using $0.3 \mathrm{~mol}$ $\%$ BrettPhos (L3) precatalyst. ${ }^{12 \mathrm{~b}}$ Combining 5 and $\mathbf{8}$ gave nilotinib base $\mathbf{9}$ in $90 \%$ yield. Alternatively, 4-methylimidazole could be introduced at the last step of the synthesis using aryl bromide $10,1 \mathrm{~mol} \% \mathrm{Pd}_{2}(\mathrm{dba})_{3}$ and $2.2 \mathrm{~mol} \% \mathbf{L 1}$. Again, the $N$-arylated product 9 was obtained as single regioisomer. This late-stage $N$-arylation route could potentially provide facile access to a large variety of nilotinib analogues.

\section{Conclusion}

We have established a catalytic method, based on mechanistic considerations, for the completely $N^{1}$-selective arylation of unsymmetric imidazoles with aryl bromides, chlorides and triflates. This study showed that imidazoles have a strong inhibitory effect on the in situ formation of catalytically-active $\mathrm{Pd}(0)$-ligand complex. By heating $\mathrm{Pd}_{2}(\mathrm{dba})_{3}$ and $\mathbf{L 1}$ in the absence of imidazoles before the reaction, no inhibitory effect was observed and the efficacy of the $\mathrm{N}$-arylation of imidazoles was improved drastically. From these findings it is clear that while imidazoles can prevent binding of $\mathbf{L} \mathbf{1}$ to the Pd, once the ligand is bound to the metal, these heterocycles do not displace it. They also point to the importance, in general, of allowing the preparation of a catalyst (or more accurately the ligand-metal complex) to take place prior to exposure of it to substrates that otherwise would tightly binding the metal in question. The utility of this method was demonstrated by the regiocontrolled syntheses of GSK2137305 and nilotinib. Highly $N^{1}$-selective couplings of 4-substituted imidazoles with aryl bromides, chlorides and triflates with $\mathrm{S}_{\mathrm{N}} \mathrm{Ar}$ or $\mathrm{Cu}$-based systems have not yet been reported. Thus, the present Pd-catalyst system complements existing $\mathrm{S}_{\mathrm{N}} \mathrm{Ar}$-based and $\mathrm{Cu}$ catalyzed $N$-arylation methods. Studies on the Pd-catalyzed arylation of other 5-membered nitrogen heterocycles are currently underway in our laboratory. 


\section{Supplementary Material}

Refer to Web version on PubMed Central for supplementary material.

\section{Acknowledgments}

This work is supported by National Institutes of Health (GM58160). S.U. thanks the Japan Society for the Promotion of Sciences (JSPS) for a Postdoctral Fellowship for Research Abroad. We thank Dr. Andrew T. Parsons for helpful discussion and help with preparation of this manuscript.

\section{References}

1. (a) Kantarjian H, et al. N Eng J Med. 2006; 354:2542.(b) Weisberg E, Manley P, Mestan J, CowanJacob S, Ray A, Griffin JD. Br J Cancer. 2006; 94:1765. [PubMed: 16721371]

2. (a) Kimura, T.; Kawano, K.; Doi, E.; Kitazawa, N.; Takaishi, M.; Ito, K.; Kaneko, T.; Sasaki, T.; Miyagawa, T.; Hagiwara, H.; Yoshida, Y. US. 20070117839. 2006. (b) Huang X, Aslanian R, Zhou W, Zhu X, Qin J, Greenlee W, Zhu Z, Zhang L, Hyde L, Chu I, Cohen-Williams M, Palani A. ACS Med Chem Lett. 2010; 1:184.

3. Harada K, Aota M, Inoue T, Matsuda R, Mihara T, Yamaji T, Ishibashi K, Matsuoka N. Eur J Pharmacol. 2006; 553:171. [PubMed: 17074317]

4. Graham JP, Langlade N, Northall JM, Roberts AJ, Whitehead AJ. Org Process Res Dev. 2011; $15: 44$.

5. See, footnote 1 in ref $6 a$.

6. (a) Kiyomori A, Marcoux JF, Buchwald SL. Tetrahedron Lett. 1999; 40:2657.(b) Klapars A, Antilla JC, Huang X, Buchwald SL. J Am Chem Soc. 2001; 123:7727. [PubMed: 11481007] (c) Antilla JC, Baskin JM, Barder TE, Buchwald SL. J Org Chem. 2004; 69:5578. [PubMed: 15307726] (d) Cristau HJ, Cellier PP, Spindler JF, Taillefer M. Chem Eur J. 2004; 10:5607. [PubMed: 15457520] (e) Ma D, Cai Q. Synlett. 2004:128.(f) Zhang H, Cai Q, Ma D. J Org Chem. 2005; 70:5164. [PubMed: 15960520] (g) Liu L, Frohn M, Xi N, Dominguez C, Hungate R, Reider PJ. J Org Chem. 2005; 70:10135. [PubMed: 16292856] (h) Jerphagnon T, van Link GPM, de Vries JG, van Koten G. Org Lett. 2005; 7:5241. [PubMed: 16268548] (i) Altman RA, Buchwald SL. Org Lett. 2006; 8:2779. [PubMed: 16774255] (j) Xie YX, Pi SF, Wang J, Yin DL, Li JH. J Org Chem. 2006; 71:8324. [PubMed: 17025338] (k) Altman RA, Koval ED, Buchwald SL. J Org Chem. 2007; 72:6190. [PubMed: 17625886] (1) Zhu L, Cheng L, Zhang Y, Xie R, You J. J Org Chem. 2007; 72:2737. [PubMed: 17348708] (m) Zhu L, Guo P, Li G, Lan J, Xie R, You J. J Org Chem. 2007; 72:8535. [PubMed: 17902694] (n) Lv X, Bao W. J Org Chem. 2007; 72:3863. [PubMed: 17432916] (o) Taillefer M, Xia N, Ouali A. Angew Chem Int Ed. 2007; 46:934.(p) Zhu L, Li G, Luo L, Guo P, Lan J, You J. J Org Chem. 2009; 74:2200. [PubMed: 19196026] (q) Liang L, Li Z, Zhou X. Org Lett. 2009; 11:3294. [PubMed: 19572739] (r) Chen H, Wang D, Wang X, Huang W, Cai Q, Ding K. Synthesis. 2010:1505.Correction: Chen H, Wang D, Wang X, Huang W, Cai Q, Ding K. Synthesis. 2011:2684.

7. (a) Collman JP, Zhong M. Org Lett. 2000; 2:1233. [PubMed: 10810715] (b) Collman JP, Zhong M, Zeng Li, Costanzo S. J Org Chem. 2001; 66:1528. [PubMed: 11312997] (c) Collman JP, Zhong M, Zhang C, Costanzo S. J Org Chem. 2001; 66:7892. [PubMed: 11701055] (d) Yu XQ, Yamamoto Y, Miyaura N. Chem Asian J. 2008; 3:1517. [PubMed: 18553321]

8. Reviews, see; (a) Bellina F, Rossi R. Adv Synth Catal. 2010; 352:1223.(b) Ley SV, Thomas AW. Angew Chem Int Ed. 2003; 42:5400.(c) Monnier F, Taillefer M. Angew Chem Int Ed. 2009; 48:6954.

9. Excellent $N^{1}$-selectivities $\left(N^{1} / N^{3}=17 / 1\right.$ and higher) were reported only for a few aryl iodide substrates, aryl bromides with bulky ortho-substituents and 4-arylimidazoles, see ref. $6 \mathrm{~b}, 6 \mathrm{k}$ and $6 \mathrm{p}$. $\mathrm{N}$-Arylation of 4-methylimidazoles with ortho-unsubstituted aryl bromides showed moderate $N^{1}$ selectivity $\left(N^{1} / N^{3}=4.1-5.7 / 1\right)$, see, ref $4,6 \mathrm{k}, 6 \mathrm{~m}, 6 \mathrm{r}$ and 28 .

10. A rare example of $\mathrm{Cu}$-catalyzed $\mathrm{N}^{1}$-selective arylation of 4-substituted imidazoles was reported using aryllead (IV) reagents as aryl donor; Elliott GI, Konopelski JP. Org Lett. 2000; 2:3055. [PubMed: 11009344] 
11. (a) Surry DS, Buchwald SL. Chem Sci. 2011; 2:27.(b) Torborg C, Beller M. Adv Synth Catal. 2009; 351:3027.(c) Hartwig JF. Nature. 2008; 455:314. [PubMed: 18800130]

12. Selected examples; (a) Fors BP, Buchwald SL. J Am Chem Soc. 2010; 132:15914. [PubMed: 20979367] (b) Fors BP, Watson DA, Biscoe MR, Buchwald SL. J Am Chem Soc. 2008; 130:13552. [PubMed: 18798626] (c) Shen Q, Ogata T, Hartwig JF. J Am Chem Soc. 2008; 130:6586. [PubMed: 18444639] (d) Marion N, Navarro O, Mei J, Stevens ED, Scott NM, Nolan SP. J Am Chem Soc. 2006; 128:4101. [PubMed: 16551119] (e) Shen Q, Shekhar S, Stambuli JP, Hartwig JF. Angew Chem Int Ed. 2005; 44:1371.

13. Wolfe JP, Åhman J, Sadighi JP, Singer RA, Buchwald SL. Tetrahedron Lett. 1997; 38:6367.

14. (a) Hicks JD, Hyde AM, Martinez Cuezva A, Buchwald SL. J Am Chem Soc. 2009; 131:16720. [PubMed: 19886610] (b) Ikawa T, Barder TE, Biscoe MR, Buchwald SL. J Am Chem Soc. 2007; 129:13001. [PubMed: 17918833] (c) Ghosh A, Sieser JE, Riou M, Cai W, Rivera-Ruiz L. Org Lett. 2003; 5:2207. [PubMed: 12816410] (d) Yin J, Buchwald SL. J Am Chem Soc. 2002; 124:6043. [PubMed: 12022838]

15. (a) Mann G, Hartwig JF, Driver MS, Fernández-Rivas C. J Am Chem Soc. 1998; 120:827.(b) Old DW, Harris MC, Buchwald SL. Org Lett. 2000; 2:1403. [PubMed: 10814458]

16. Lundgren RJ, Stradiotto M. Angew Chem Int Ed. 2010; 49:8686.

17. (a) Wagaw S, Yang BH, Buchwald SL. J Am Chem Soc. 1998; 120:6621.(b) Wagaw S, Yang BH, Buchwald SL. J Am Chem Soc. 1999; 121:10251.(c) Arterburn JB, Rao KV, Ramdas R, Dible BR. Org Lett. 2001; 3:1351. [PubMed: 11348232] (d) Mauger C, Mignani G. Adv Synth Catal. 2005; 347:773.(e) Thiel OR, Achmatowicz MM, Reichelt A, Larsen RD. Angew Chem Int Ed. 2010; 49:8395.

18. (a) Shen Q, Hartwig JF. J Am Chem Soc. 2006; 128:10028. [PubMed: 16881628] (b) Surry DS, Buchwald SL. J Am Chem Soc. 2007; 129:10354. [PubMed: 17672469] (c) Vo GD, Hartwig JF. J Am Chem Soc. 2009; 131:11049. [PubMed: 19591470] (d) Schulz T, Torborg C, Enthaler S, Schäffner B, Dumrath A, Spannenberg A, Neumann H, Börner A, Beller M. Chem Eur J. 2009; 15:4528. [PubMed: 19322847]

19. Fors BP, Buchwald SL. J Am Chem Soc. 2009; 131:12898. [PubMed: 19737014]

20. (a) Wan Y, Alterman M, Hallberg A. Synthesis. 2002:1597.(b) Andrus MB, Mettath SN, Song C. J Org Chem. 2002; 67:8284. [PubMed: 12423172] (c) Burns, CJ.; Harte, MF.; Palmer, JT. WO. 2008058341. 2008. (d) Lee, C., et al. WO. 2010027236. 2010.

21. Anderson KW, Tundel RE, Ikawa T, Altman RA, Buchwald SL. Angew Chem Int Ed. 2006; 45:6523.

22. (a) Mathews CJ, Smith PJ, Welton T. J Mol Catal A. 2003; 206:77.(b) Haneda S, Ueba C, Eda K, Hayashi M. Adv Synth Catal. 2007; 349:833.

23. Benefical effects of the catalyst premixing were previously reported. (a) Wolfe JP, Buchwald SL. J Org Chem. 2000; 65:1144. [PubMed: 10814066] (b) Ueda S, Su M, Buchwald SL. Angew Chem Int Ed. 2011; 50:8944.See also ref 12c. Toluene-dioxane mixed solvent gave better result than toluene probably due to higher solubility of imidazole derivative in the mixed solvent.

24. Single-component Pd-ligand precatalysts have proven to be an ideal source for the in situ production of catalytically active $\mathrm{Pd}(0)$-ligand complex. However, preparation of Pd-L1 precatalyst was not successful. For single-component palladium precatalysts; (a) Biscoe MR, Fors BP, Buchwald SL. J Am Chem Soc. 2008; 130:6686. [PubMed: 18447360] (b) Kinzel T, Zhang Y, Buchwald SL. J Am Chem Soc. 2010; 132:14073. [PubMed: 20858009]

25. The two peaks might correspond to the comformers that arise from rotation around aromatic C-P bond. The C-P bond rotamers were previously observed in the Pd-biarylphosphine complex, see; ref $12 \mathrm{~b}$. Although isolation of the $\operatorname{Pd}(0)-\mathbf{L} 1$ complex was not successful, formation of $\operatorname{Pd}(0)-\mathbf{L} \mathbf{1}$ complex was confirmed by ESI-MS analysis of the crude mixture. See the supporting information.

26. 4-Bromobenzaldehyde: 154.5 USD/100 g; 4-chlorobenzaldehyde: 38.7 USD/250 g. (SigmaAldrich, 2011)

27. Breitenstein, W.; Furet, P.; Jacob, S.; Manley, PW. WO. 2004005281. 2004.

28. These reactions gave 5.5:1 or 5:1 mixture of $\mathrm{N}^{1}$ - and $\mathrm{N}^{3}$-arylated products; Huang WS, Shakespeare WC. Synthesis. 2007:2121.See also ref. 6r. 
29. Although regioisomeric ratio was not disclosed, Cu-catalyzed $\mathrm{N}$-arylation of 4-methylimidazole with $\mathbf{4}$ or $\mathbf{1 0}$ was reported. (a)Yeori A, Wang Y, Li J, Zhu J, Lifshitz-Liron R, He X. WO.

2010060074. 2010(b)Wang Y, Li K, Vinod K, Zhu J, Lifshitz-Liron R, Mistry DN, Vasoya SL, Ariyamuthu S, Pilarski G, He X. WO. 2010009402. 2010 
<smiles>Cc1cn(-c2cc(NC(=O)c3ccc(C)c(Nc4nccc(-c5cccnc5)n4)c3)cc(C(F)(F)F)c2)cn1</smiles>

Nilotinib (Tasigna $\left.{ }^{8}\right)$

BCR-ABL inhibitor (Novartis)

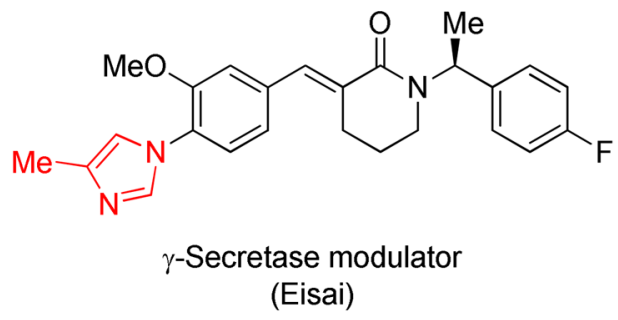

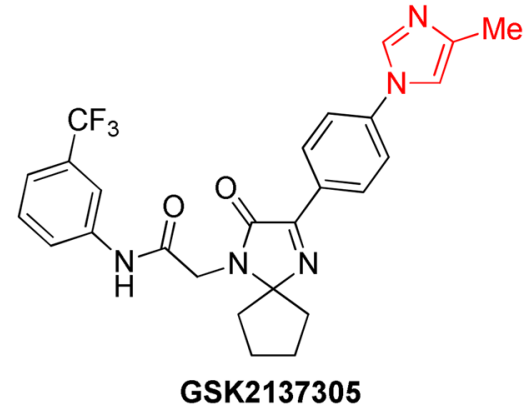

Glycine transporter inhibitor (GlaxoSmithKline)

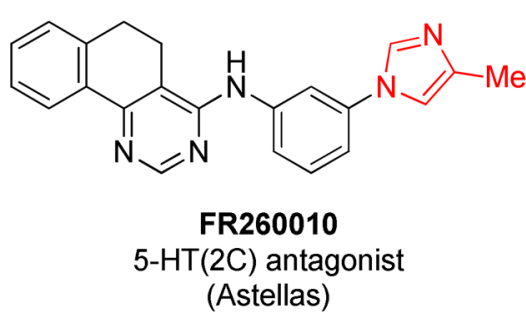

Figure 1.

Biologically active compounds containing $N$-arylimidazole motif 


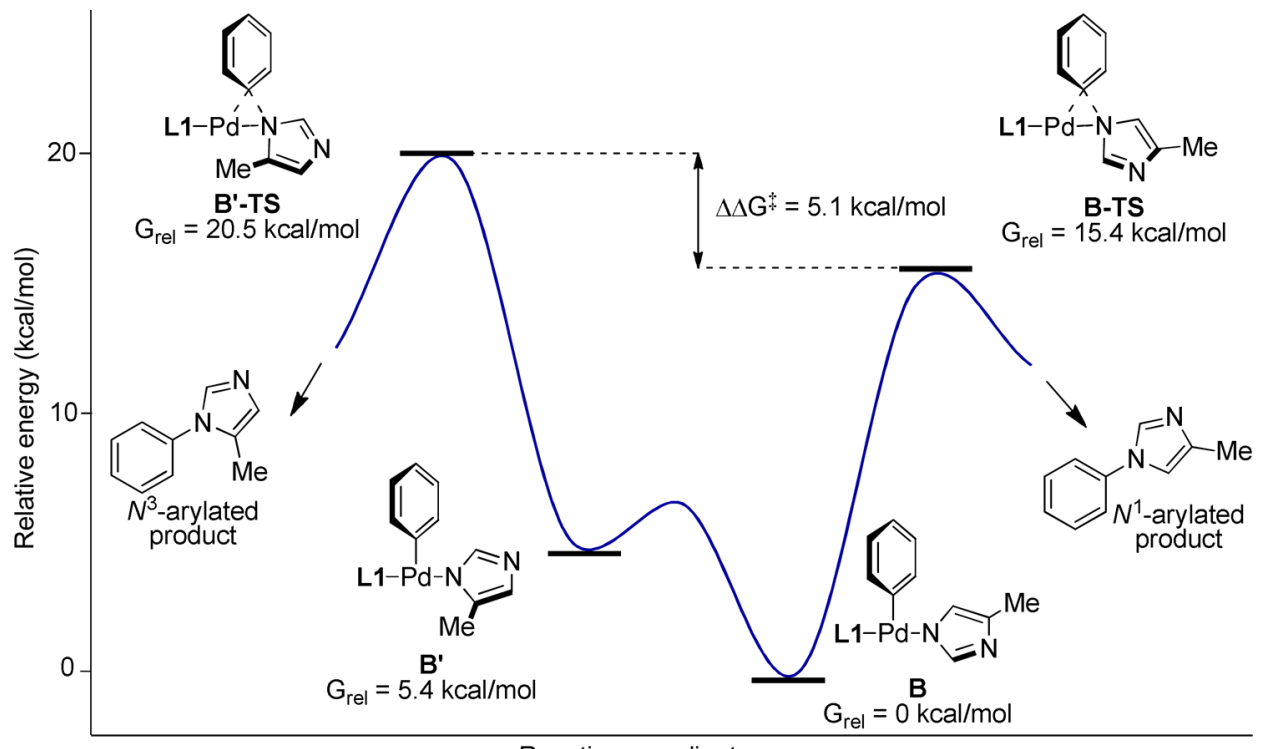

Reaction coordinate

Figure 2.

Energy diagram for reductive elimination with $\mathbf{L 1}$ 
(a)

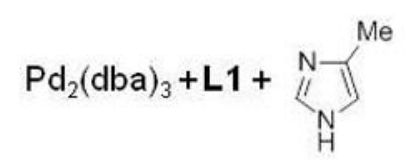

$\checkmark \mathrm{L1}$

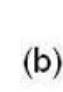

(b) $\quad \mathrm{Pd}_{2}(\mathrm{dba})_{3}+\mathrm{L1}$

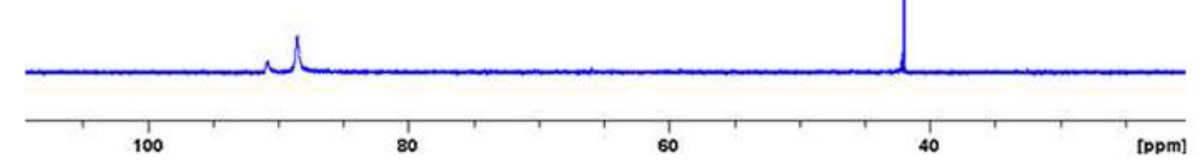

Figure 3.

${ }^{31} \mathrm{P}$ NMR spectra of the solution of $\mathbf{L} \mathbf{1}$ and $\mathrm{Pd}_{2}(\mathrm{dba})_{3}$ in the presence (a) or absence (b) of 4methylimidazole (16 equiv to $\mathrm{Pd}$ ) 


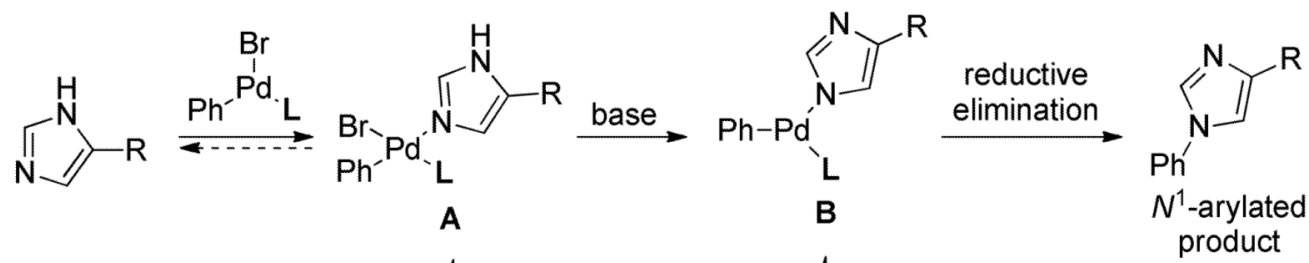<smiles>C=CC(=C)C=C</smiles>

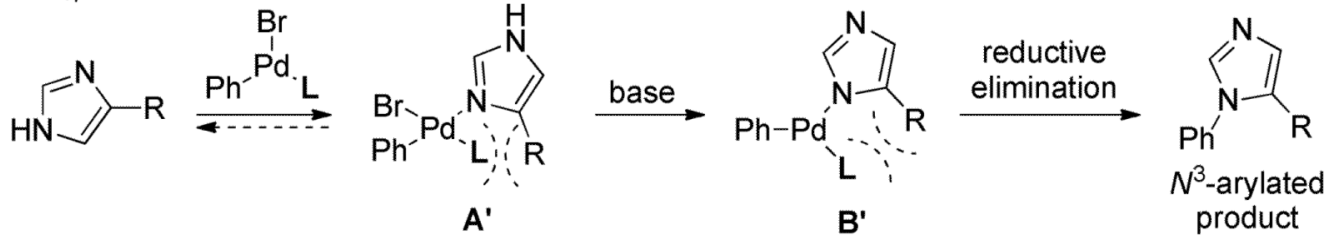

Scheme 1.

Presumed intermediates for the Pd-catalyzed $N$-arylation of 4-substituted imidazoles 


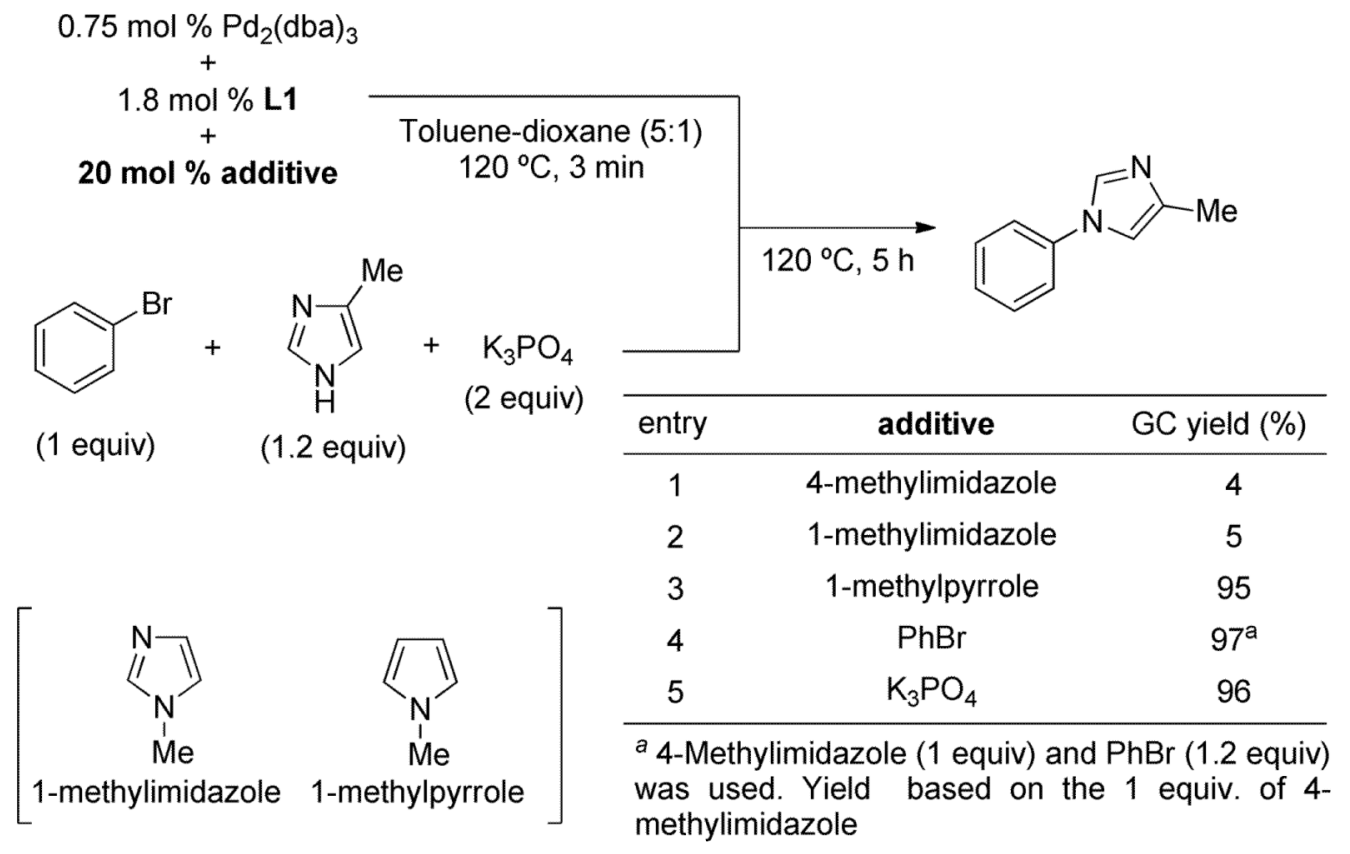

Scheme 2.

Inhibitory effect of imidazoles on the Pd-catalyzed $N$-arylation of 4-methylimidazole 

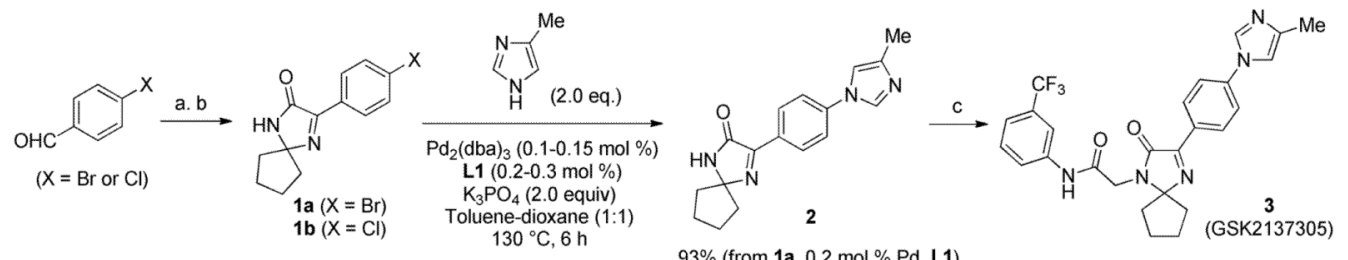

$93 \%$ (from 1a, $0.2 \mathrm{~mol} \%$ Pd, L1 $92 \%$ (from 1 b, $0.3 \mathrm{~mol} \% \mathrm{Pd}, \mathrm{L} 1$ )

Scheme 3.

Synthesis of GSK2137305

Reagents and conditions; a) $\mathrm{NaCN}$ (1.1 equiv), $\mathrm{NH}_{4} \mathrm{OAc}$ ( 3.0 equiv), aq. $\mathrm{NH}_{4} \mathrm{OH}, \mathrm{EtOH}, \mathrm{rt}$, $4 \mathrm{~h}$ then, cyclopentanone ( 2.5 equiv), $\mathrm{NaOEt}\left(0.1\right.$ equiv), $n-\mathrm{BuOH}, 80^{\circ} \mathrm{C}, 12 \mathrm{~h}, 38 \%$ (X= $\mathrm{Br}), 32 \%(\mathrm{X}=\mathrm{Cl})$. b) DDQ (1.1 equiv), EtOAc, $\left.60{ }^{\circ} \mathrm{C}, 1 \mathrm{~h}, 89 \%(\mathrm{X}=\mathrm{Br}), 90 \%(\mathrm{X}=\mathrm{Cl}) . \mathrm{c}\right)$ Chloroacetyl chloride (1.1 equiv), 3 -aminobenzotrifluoride (1.15 equiv), $\mathrm{KOH}$ (2.5 equiv), NMP, $82 \%$. 


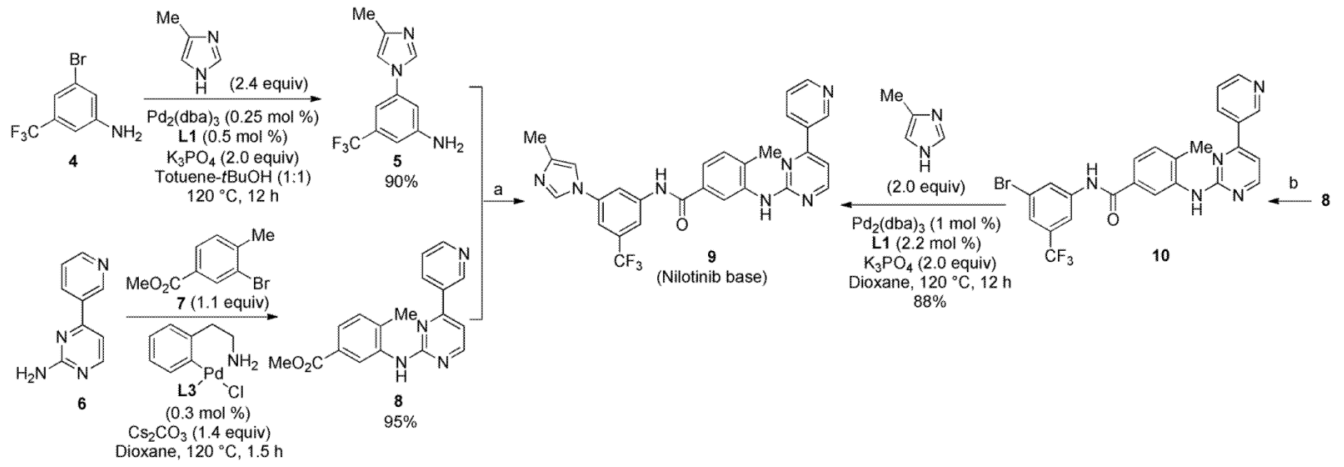

Scheme 4.

Synthesis of nilotinib base

Reagents and conditions; a) KOtBu (5.5 equiv), THF, rt, 12 h, 90\%, b) 4 (1.05 equiv), $\mathrm{KO} t \mathrm{Bu}$ (5.5 equiv), THF, rt, $12 \mathrm{~h}, 85 \%$. 


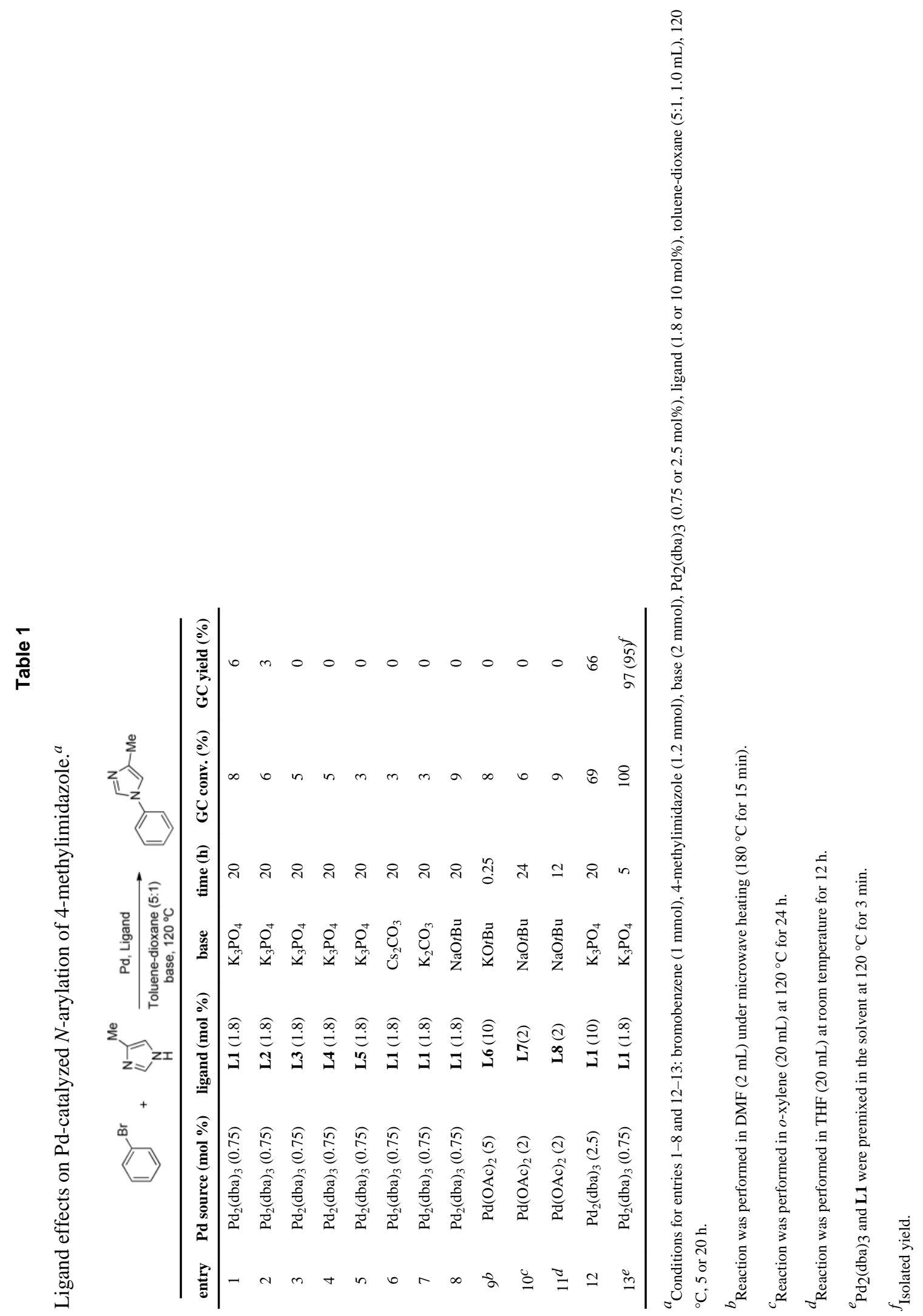

J Am Chem Soc. Author manuscript; available in PMC 2013 January 11. 
Table 2

Substrate scope of $N^{1}$-selective arylation of unsymmetric imidazoles ${ }^{a}$

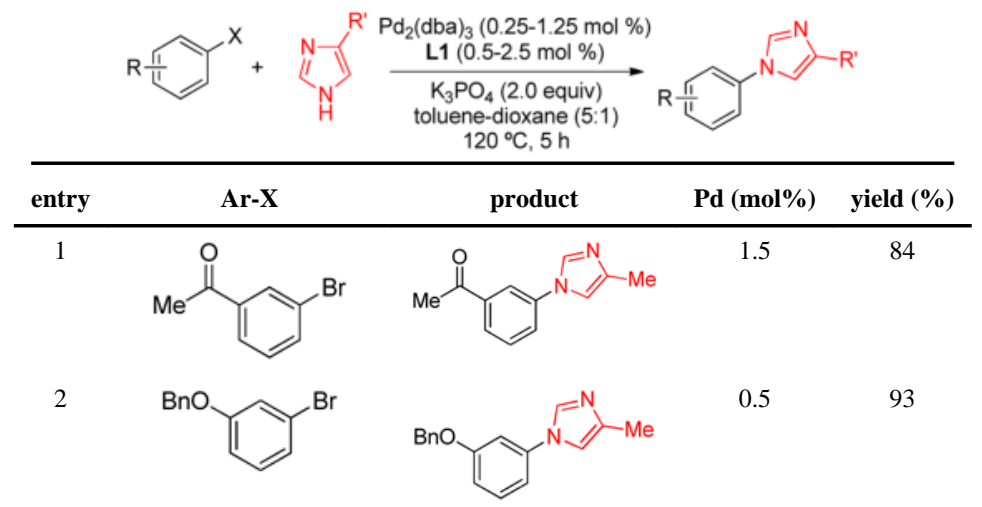

3

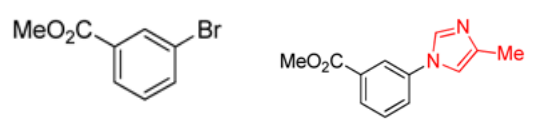

0.5

91<smiles>COC(=O)c1cncc(Br)c1</smiles><smiles>COC(=O)c1cncc(-n2cnc(C)c2)c1</smiles>

1.5

5<smiles>Brc1cnc2ccccc2c1</smiles><smiles>Cc1cn(-c2cnc3ccccc3c2)cn1</smiles>

0.5

94

6<smiles>Fc1ccccc1Br</smiles><smiles>Cc1cn(-c2ccccc2F)cn1</smiles>

7<smiles>N#Cc1ccccc1Br</smiles><smiles>Cc1cn(-c2ccccc2C#N)cn1</smiles><smiles>CC(C)(C)OC(=O)N1CCN(c2cccc(Br)n2)CC1</smiles><smiles>Cc1cn(-c2cccc(N3CCN(C(=O)OC(C)(C)C)CC3)n2)cn1</smiles>

9<smiles>Cc1nc2cc(Cl)ccc2s1</smiles><smiles>Cc1cn(-c2ccc3sc(C)nc3c2)cn1</smiles>

10<smiles>CCCOc1ccc(C(=O)OC)cc1OC</smiles><smiles>COc1cc(C(C)=O)ccc1-n1cnc(C)c1</smiles>

11<smiles>CCOc1cc(C)ccn1</smiles><smiles>Cc1ccnc(-n2cnc(C)c2)c1</smiles>

2

80

1.5

79

94

88 


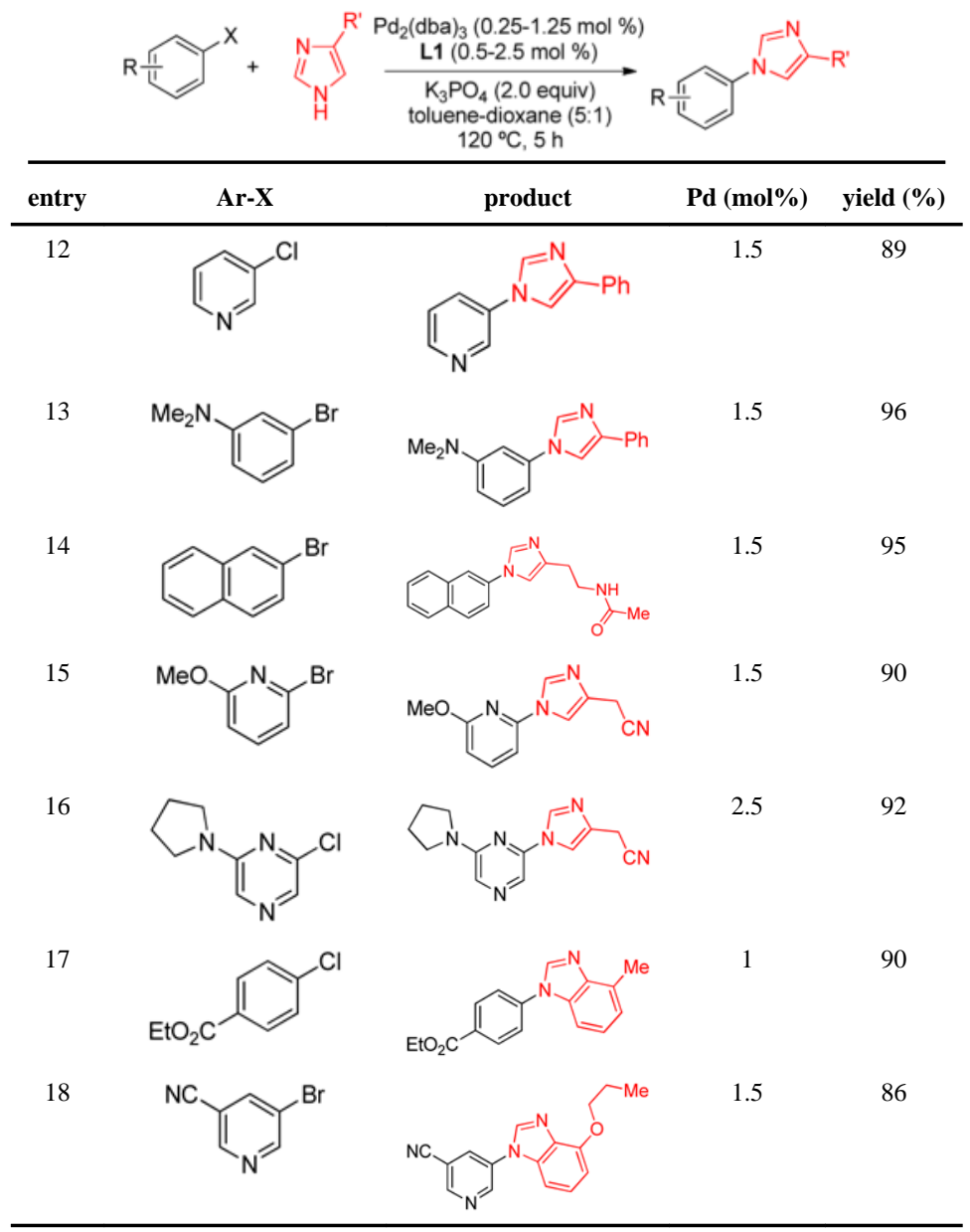

${ }^{a}$ Ar-X (1 mmol), 4-substituted imidazole (1.1-1.2 mmol), $\mathrm{K}_{3} \mathrm{PO}_{4}(2 \mathrm{mmol}), \mathrm{Pd}_{2}(\mathrm{dba}) 3$ ( $\left.0.25-1.25 \mathrm{~mol} \%\right), \mathbf{L 1}(0.5-2.5 \mathrm{~mol} \%)$, toluene/dioxane $(5: 1,1.0 \mathrm{~mL}), 120^{\circ} \mathrm{C}, 5 \mathrm{~h} . \mathrm{Pd}_{2}(\mathrm{dba}) 3$ and $\mathbf{L} \mathbf{1}$ were premixed in the solvent at $120^{\circ} \mathrm{C}$ for $3 \mathrm{~min}$. Isolated yield, average of two runs. 